Diabetologia 10,761-765 (1974)

(C) by Springer-Verlag 1974

\title{
Failure of 6-Aminonicotinamide to Inhibit the Potentiating Effect of Leucine and Arginine on Glucose-Induced Insulin Release in Vitro*
}

\author{
M.J. MacDonald, H.P.T. Ammon', 'T. Patel, and J. Steinke ${ }^{2}$ \\ E.P. Joslin Research Laboratory, Harvard Medical School and Peter Bent Brigham Hospital, and the Elliott P. Joslin \\ Research Foundation, Inc., Boston, Mass., USA and the Dept. of Pharmacology, University of Erlangen-Nurenberg, \\ W. Germany \\ ${ }^{1}$ Department of Pharmacology, University of Erlangen-Nurenberg, W. Germany. ${ }^{2}$ Deceased May 21,1973
}

Received: January 28, 1974, and in revised form: July 16, 1974.

\begin{abstract}
Summary. 6-aminonicotinamide (6-AN), which decreases the activity of the hexosemonophosphate pathway of pancreatic islets as well as the insulin releasing effect of glucose, was used to determine whether the potentiating effect of leucine and arginine on glucoseinduced insulin release is dependent upon normal function of the hexosemonophosphate pathway in pancreatic islets. In control islets, at low glucose concentrations (1 $\mathrm{mg} / \mathrm{ml})$, or in the absence of glucose, insulin release induced by these amino acids was negligible. At high glucose concentrations (3 $\mathrm{mg} / \mathrm{ml})$, which markedly stimulated insulin release (584 $\mu \mathrm{U} / 5$ islets $/ 90 \mathrm{~min}), 1$ and $10 \mathrm{mM}$ leucine and $10 \mathrm{mM}$ arginine increased insulin release by another 250 to $300 \mu \mathrm{U}$. Islets from animals treated with 6 -AN released significantly less insulin in response to glucose alone or glucose plus leucine or
\end{abstract}

arginine than control islets. However, the potentiating effect of these amino acids on insulin release from islets of animals treated with 6 -AN was still similar to that observed in control islets and the total insulin released in the presence of 1 or $10 \mathrm{mM}$ leucine or $10 \mathrm{mM}$ arginine plus $3 \mathrm{mg} / \mathrm{ml}$ glucose was about the same as that observed in control islets in the presence of $3 \mathrm{mg} / \mathrm{ml}$ glucose alone. The data are consistent with the hypothesis that glucose exerts a permissive effect upon the insulinogenic actions of leucine and arginine, but that glucose oxidation through the hexosemonophosphate pathway is not important for the potentiation of glucose-induced insulin release by these amino acids.

Key words: Glucose, 6-aminonicotinamide, leucine, arginine, insulin release, hexosemonophosphate pathway.
Recently it was shown that normal function of the hexosemonophosphate pathway of the pancreatic beta cell is critical for glucose-induced insulin release. When 6-aminonicotinamide (6-AN), an antimetabolite of pyridine nucleotide synthesis [1], was administered to rats, they became transiently diabetic. Isolated pancreatic islets from these rats showed a marked decrease in insulin release when challenged with glucose [2], aminophylline [3], or cyclic AMP [4] and a marked decrease in the activity of the hexosemonophosphate pathway as evidenced by decreased oxidation of $1 .{ }^{14} \mathrm{C}$. glucose to ${ }^{14} \mathrm{CO}_{2}$, whereas that from $6-{ }^{14} \mathrm{C}$-glucose was essentially unchanged [3]. Tolbutamide, however, is able to overcome the block in insulin secretion without overcoming the block in the oxidation of glucose at C-1 caused by 6 -AN, suggesting that normal function of the hexosemonophosphate pathway is not necessary for insulin release by tolbutamide [3].

It has been well documented that leucine and arginine stimulate insulin release in vitro $[5-10]$ and in vivo $[11-17]$. There is also evidence that insulin release from the isolated pancreatic islet stimulated by leucine and arginine is dependent on the glucose concentration, but leucine seems to be less dependent upon

* Supported by U.S.P.H.S. Grants AM 15721 and AM 05077 and the P. Martini Foundation, Frankfurt, W. Germany. glucose in this respect than is arginine $[5,10,18,19]$. Since leucine and arginine, similar to tolbutamide, are most effective in stimulating insulin release in the presence of high glucose concentrations, but since the the activity of the hexosemonophosphate pathway of the pancreatic islet is independent of the glucose concentration $[20,21]$, it is possible that the stimulation of insulin release by leucine and arginine is also independent of the activity of the hexosemonophosphate pathway. To test this hypothesis we investigated the effect of leucine and arginine on insulin release and glucose oxidation by isolated islets of rats treated with 6 -AN. The data indicate that potentiation of glucoseinduced insulin release by these amino acids is not affected by 6-AN and that a normal rate of glucose oxidation through the hexosemonophosphate pathway is not necessary for these amino acids to potentiate insulin release.

\section{Materials and Methods}

\section{Experimental Procedure}

Female rats, weighing about $200 \mathrm{~g}$, of the Charles River CD strain were used. They were allowed free access to standard Purina chow and tap water. Rats, injected with 6-aminonicotinamide (Aldrich Chemical 
Co., Inc., Milwaukee, Wis.) $35 \mathrm{mg} / \mathrm{kg}$ intraperitoneally six hours before they were sacrificed, and control rats were studied. Their pancreata were removed under ether anesthesia and the pancreatic islets isolated using a collagenase (Worthington Biochemical Corp., Freehold, N.J.) technique [22]. The Hank's solution used for isolation of islets from the 6-aminonicotinamide treated rats contained $3.5 \mathrm{mg} / 100 \mathrm{ml} 6$-aminonicotinamide.

\section{Insulin Release}

Insulin release studies were performed with an incubation medium containing $2 \%$ albumin (bovine albumin powder fraction $V$, Armour Pharmaceutical Co., Chicago, Illinois) in Krebs-Ringer bicarbonate buffer, $\mathrm{pH} 7.4$, alone or with glucose $1 \mathrm{mg} / \mathrm{ml}$ or $3 \mathrm{mg} /$ $\mathrm{ml}$, leucine 1 or $10 \mathrm{mM}$, or arginine 1 or $10 \mathrm{mM}$. The incubation medium used for islets of the 6-AN treated animals also contained 6-AN, $3.5 \mathrm{mg} / 100 \mathrm{ml}$. Five islets per flask, in $1.0 \mathrm{ml}$ medium were incubated in a Dubnoff metabolic shaker at $37^{\circ} \mathrm{C}$ for $90 \mathrm{~min}$ and gassed with $95 \% \quad \mathrm{O}_{2}: 5 \% \mathrm{CO}_{2}$. Insulin. released into the medium was measured by a double antibody immunoassay [23], employing proinsulin-free rat insulin as a standard (courtesy of Novo Laboratories).

\section{Glucose Oxidation}

For the studies with ${ }^{14} \mathrm{C}$ labelled glucose 17 to 20 islets were placed into center wells of scintillation counter vials containing $0.2 \mathrm{ml}$ of the incubation medium used for insulin release studies, except that all solutions contained $3 \mathrm{mg} / \mathrm{ml}$ glucose labelled at $\mathrm{C}-1$ or C-6 with a specific radioactivity of $1 \mu \mathrm{Ci} / \mathrm{mg}$ and the desired concentrations of 6 - $\mathrm{AN}$, leucine or arginine. The scintillation vials were stoppered and incubated at $37^{\circ} \mathrm{C}$ for three hours in a Dubnoff metabolic shaker. The vials were gassed with $95 \% \mathrm{O}_{2}: 5 \% \mathrm{CO}_{2}$ for the first five minutes of the incubation. The reaction was terminated by injecting $0.2 \mathrm{ml} 10 \mathrm{~N} \mathrm{H}_{2} \mathrm{SO}_{4}$ into the center wells. The $\mathrm{CO}_{2}$ was collected overnight in $1 \mathrm{ml}$ hyamine injected into the vials and the ${ }^{14} \mathrm{CO}_{2}$ counted in $10 \mathrm{ml}$ of scintillation fluid $(42 \mathrm{ml}$ Liquiflor, New England Nuclear, Boston, Mass. in 11 of toluene) in an automatic scintillation counter (Isocap 300, Nuclear Chicago). Blanks were made by placing incubation media with labelled glucose into center wells without islets. The cpm obtained from the blanks were subtracted from the cpm of the center wells containing islets.

\section{Calculations}

Insulin release is expressed as $\mu \mathrm{U}$ immunoreactive insulin released into $1.0 \mathrm{ml}$ medium per five islets per $90 \mathrm{~min}$ incubation period. The glucose oxidation data are expressed as percentages, defining the average ${ }^{14} \mathrm{CO}_{2} \mathrm{cpm}$ metabolized from glucose alone during the same series of experiments as $100 \%$. Student's t test was used for statistical analysis. Values are expressed as means \pm SEM.

\section{Results}

\section{Effect of Glucose on Insulin Release by Leucine and Arginine}

The stimulation of insulin release by 1 or $10 \mathrm{mM}$ leucine and 1 or $10 \mathrm{mM}$ arginine in the absence of glucose was negligible (Figs. 1 and 2). In the presence of $1 \mathrm{mg} / \mathrm{ml}$ glucose, only $10 \mathrm{mM}$ leucine stimulated insulin release $(23 \pm 4$ vs. $79 \pm 12 \mu \mathrm{U} / 5$ islets $/ 90 \mathrm{~min}$, $p<0.02)$. In control islets insulin release, stimulated by $3 \mathrm{mg} / \mathrm{ml}$ glucose, was $584 \pm 73$ and $516 \pm 52 \mu \mathrm{U}$ for the leucine and arginine experiments respectively. The further addition of leucine to make concentrations of 1 and $10 \mathrm{mM}$ significantly increased insulin release, in the presence of $3 \mathrm{mg} / \mathrm{ml}$ glucose, to $836 \pm 58(p<$ $0.02)$ and $892 \pm 65 \mu \mathrm{U}(p<0.01$, compared to $3 \mathrm{mg} / \mathrm{ml}$ glucose alone), respectively. The addition of arginine to make a concentration of $1 \mathrm{mM}$ did not increase insulin

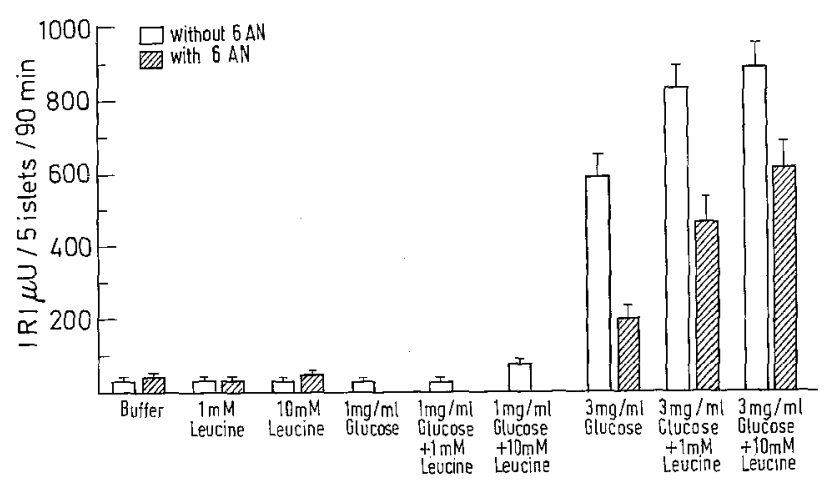

Fig. 1. Effect of leucine with and without glucose on insulin release from isolated pancreatic islets from control rats and rats treated with 6 -aminonicotinamide

Results are expressed as $\mu \mathrm{U}$ immunoreactive insulin (IRI) released into the medium per 5 islets per $90 \mathrm{~min}$ incubation time, $(\mathrm{N}=17-24)$, mean \pm SEM.

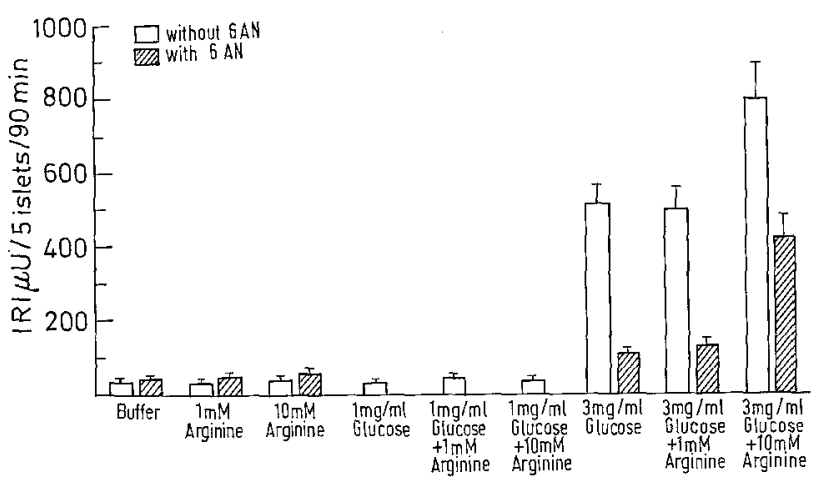

Fig. 2. Effect of arginine with and without glucose on insulin release from isolated pancreatic islets from control rats and rats treated with 6 -aminonicotinamide

Results are expressed as $\mu U$ immunoreactive insulin (IRI) released into the medium per 5 islets per 90 min incubation time, $(\mathrm{N}=17-18)$, mean \pm SEM. 
release, but insulin release by $10 \mathrm{mM}$ arginine in the presence of $3 \mathrm{mg} / \mathrm{ml}$ glucose was $790 \pm 101 \mu \mathrm{U}(p<$ 0.01 , compared to $3 \mathrm{mg} / \mathrm{ml}$ glucose alone).

\section{Effect of 6-Aminonicotinamide on Insulin Release by Glucose, Leucine and Arginine}

6-AN reduced insulin release by $3 \mathrm{mg} / \mathrm{ml}$ glucose to $190 \pm 38 \mu \mathrm{U}$ in the leucine experiments and to $100 \pm$ $8 \mu \overline{\mathrm{U}}$ in the arginine experiments $(p<0.01)$. The reduction of insulin release by 6 -AN was about $400 \mu \mathrm{U}$ in all experiments with the amino acids, as well as with glucose, suggesting that 6-AN affected a process separate from the insulinogenic effect of the amino acids. Likewise, the potentiation of insulin release by leucine and arginine was the same, and approximately additive to that of $3 \mathrm{mg} / \mathrm{ml}$ glucose, regardless of whether control islets or islets from 6-AN-treated animals were employed, suggesting that the potentiating effect of these amino acids was not via the metabolism of glucose through the hexosemonophosphate pathway. Potentiation of insulin release by $1 \mathrm{mM}$ leucine was $252 \mu \mathrm{U}$ in the absence of $6-\mathrm{AN}$ and $271 \mu \mathrm{U}$ in the presence of $6-\mathrm{AN}$. With $10 \mathrm{mM}$ leucine, it was $308 \mu \mathrm{U}$ in the absence of $6-\mathrm{AN}$ and $423 \mu \mathrm{U}$ in presence of 6 -AN (Fig. 1). $1 \mathrm{mM}$ arginine did not potentiate insulin release in the presence or absence of $6-\mathrm{AN}$, but $10 \mathrm{mM}$ arginine potentiated insulin release by $274 \mu \mathrm{U}$ in the absence of $6-\mathrm{AN}$ and $308 \mu \mathrm{U}$ in the presence of 6-AN (Fig. 2).

\section{Discussion}

6-AN has been shown to markedly decrease the activity of the hexosemonophosphate pathway in brain, kidney, and the islets of Langerhans [2, 24, 25, 26]. 6-AN is incorporated into NADP and NAD forming 6-amino-NADP and 6-amino-NAD, which do not transfer hydrogen. In addition, 6-AN decreases NADP and NAD synthesis. 6-amino-NADP is a competitive inhibitor of NADP-dependent enzymes such as glucose-6-phosphate dehydrogenase, 6-phosphogluconate dehydrogenase, and glutathione reductase $[1,27,28]$. However, no inhibition of NAD-dependent enzrymes has yet been observed [29]. In isolated pancreatic islets of rats treated with 6 -AN the concentrations of NADP and NADPH are decreased $30 \%$, whereas the concentrations of NAD and NADH are normal $[4,26]$.

Insulin release by $3 \mathrm{mg} / \mathrm{ml}$ glucose was reduced about $70 \%$ by the addition of $6-\mathrm{AN}$. The further addition of leucine to make a concentration of 1 or $10 \mathrm{mM}$, or arginine to make a concentration of $10 \mathrm{mM}$, restored insulin release to values similar to those observed in control islets with $3 \mathrm{mg} / \mathrm{ml}$ glucose. To eliminate the possibility that leucine or arginine restored insulin release by increasing the activity of the hexosemonophosphate pathway, the effect of these amino acids on ${ }^{14} \mathrm{CO}_{2}$ production from ${ }^{14} \mathrm{C}-1$ and ${ }^{14} \mathrm{C}-6$ glucose was studied. No significant change in the activity of the hexosemonophosphate pathway could be observed, indicating that leucine and arginine do not potentiate

Table 1. Effect of lewcine and arginine in the presence of glucose, $3 \mathrm{mg} / \mathrm{ml}$, on ${ }^{14} \mathrm{CO}_{2}$ production from ${ }^{14} \mathrm{C}-1$ or, ${ }^{14} \mathrm{C}-6 \mathrm{glucose}$ by isolated pancreatic islets from rats treated with 6-aminonicotinamide

\begin{tabular}{|c|c|c|c|c|c|c|}
\hline \multirow[t]{3}{*}{ Addition and concentration } & \multicolumn{6}{|c|}{$\begin{array}{l}\text { Rate of }{ }^{14} \mathrm{CO}_{2} \text { production } \\
\text { Position of label in }{ }^{14} \text {-C-glucose }\end{array}$} \\
\hline & \multicolumn{3}{|l|}{$\mathrm{C}-1$} & \multicolumn{3}{|l|}{$\mathrm{C}-6$} \\
\hline & $\mathrm{cpm}$ & $\%$ of control & $p$ value & cpm & $\%$ of control & $p$ value \\
\hline Glucose alone (control) & $231 \pm 24$ & $100 \pm \overline{10}$ & $(0.01)$ & $185 \pm 19$ & $100 \pm 10$ & (N.S.) \\
\hline Glucose $+6-\mathrm{AN}$ & $114 \pm 18$ & $49 \pm 8$ & - & $153 \pm 17$ & $83 \pm 9$ & - \\
\hline Glucose + 6-AN + Leucine $1 \mathrm{mM}$ & $140 \pm 12$ & $61 \pm 5$ & (N.S.) & $114 \pm 7$ & $63 \pm 4$ & $(0.05)$ \\
\hline Glucose + 6-AN + Leucine $10 \mathrm{mM}$ & $143 \pm 12$ & $62 \pm 5$ & (N.S.) & $137 \pm 11$ & $74 \pm 6$ & (N.S.) \\
\hline Glucose $+6-\mathrm{AN}+$ Arginine $1 \mathrm{mM}$ & $150 \pm 7$ & $65 \pm 3$ & (N.S.) & $137 \pm 6$ & $74 \pm 3$ & (N.S.) \\
\hline Glucose + 6-AN + Arginine $10 \mathrm{mM}$ & $131 \pm 7$ & $57 \pm 3$ & (N.S.) & $131 \pm 9$ & $71 \pm 5$ & (N.S.) \\
\hline
\end{tabular}

Results are expressed as epm/10 islets/3 hrs incubation and as percentages of the controls, means \pm SEM. $p$ values represent the significance compared to glucose $+6-\mathrm{AN}$. Incubation media contained $3 \mathrm{mg} / \mathrm{ml}$ glucose, specific radioactivity $1 \mu \mathrm{Ci} / \mathrm{mg}$ plus the agents shown. $(\mathbf{n}=11-18)$

\section{Effect of 6-Aminonicotinamide on Glucose Oxidation}

The rate of oxidation of $1{ }^{1-14} \mathrm{C}$-glucose to ${ }^{14} \mathrm{CO}_{2}$ by islets from 6-AN-treated rats was only $49 \pm 8 \%$ of that of islets from control rats $(p<0.01)$, whereas the rate of oxidation of ${ }^{6-14} \mathrm{C}$-glucose to ${ }^{14} \mathrm{CO}_{2}$ by islets from 6 - $A N$-treated rats was $83 \pm 9 \%$ of that of islets from control rats, which was not a statistically significant decrease. Leucine and arginine did not signifieantly alter the effect of 6-AN upon glucose oxidation at C-1 or C-6 (Table 1). glucose-induced insulin release by overcoming the block in the hexosemonophosphate pathway caused by 6-AN.

In the absence of glucose, leucine and arginine did not stimulate insulin release. When $1 \mathrm{mg} / \mathrm{ml}$ glucose was employed, $10 \mathrm{mM}$ leucine stimulated insulin release, but only slightly. In the presence of $3 \mathrm{mg} / \mathrm{ml}$ glucose, 1 and $10 \mathrm{mM}$ leucine and $10 \mathrm{mM}$ arginine greatly potentiated insulin release. These findings are similar to those of others who observed slight or no 
insulin release in the absence of glucose or in the presence of low glucose $[6,7,10,18]$ and marked potentiation of insulin release by these amino acids in the presence of high glucose $[7,11,12]$. These data suggest that although it is possible that leucine and arginine stimulate insulin release by a mechanism of their own, the major insulinogenic effect of these amino acids is to further increase glucose-induced insulin release.

The potentiation of insulin release by leucine and arginine was the same in the presence of $6-\mathrm{AN}$ as in the absence of 6-AN. This demonstrates that the potentiating effect of leucine and arginine on glucose-induced insulin release, in contrast to the stimulatory effect of glucose alone, is still present when the activity of the hexosemonophosphate pathway is decreased and when the level of NADPH of the B-cell is decreased. It is unlikely that the potentiating effect of these amino acids on insulin release is related to a fuel function of glucose or of these amino acids because, as this study and others have shown $[19,30]$, these amino acids do not significantly affect glucose oxidation by the beta cell. Furthermore, if the B-cell required a fuel to be responsive to leucine, leucine itself could serve as its own fuel, because leucine is oxidized by the pancreatic islet at a rate sufficient to provide any energy necessary to support insulin release [19]. Since leucine itself did not stimulate insulin release in the absence of glucose it is unlikely that leucine acts as an insulin secretagogue by a mechanism involving its metabolism. Arginine cannot potentiate insulin release by its complete catabolism because it is not oxidized to $\mathrm{CO}_{2}$ by the pancreatic islet [19]. When glucose phosphorylation is inhibited in pieces of pancreas by mannoheptulose in the presence of $3 \mathrm{mg} / \mathrm{ml}$ glucose, $10 \mathrm{mM}$ leucine still stimulates insulin release [10]. These data and the data of this study suggest that leucine and arginine potentiate glucose-induced insulin secretion by a mechanism largely independent of the metabolism of glucose and their own metabolism. Therefore, these data are consistent with the hypothesis that these amino acids potentiate insulin release by interacting with receptors which have been postulated to exist on the membrane of the beta cell $[11,31]$.

The above viewpoint should not obscure the possibility that 6 -AN affects insulin release in such a complex way that it cannot be fully explained by an effect on the hexosemonophosphate pathway. For example, the present results do not completely exclude the possibility that 6-AN alters the redox state of the B-cell in a general, nonspecific way; or that an altered redox state interferes with the action of membrane sulfhydryl groups which have been implicated in insulin release [32].

\section{References}

1. Dietrich, L.S., Friedland, J.M., Kaplan, A.: Pyridine nucleotide metabolism: Mechanism of action of the niacin antagonist, 6 -aminonicotinamide. J. biol. Chem. 233, 964-968 (1958)
2. Ammon, H.P.T., Steinke, J.: 6-aminonicotinamide (6-AN) as a diabetogenic agent: In vitro and in vivo studies in the rat. Diabetes $21,143-148$ (1972)

3. Ammon, H.P.T., Steinke, J.: Effect of 6-aminonicotinamide on insulin release and $\mathrm{C}$-14-glucose oxidation by isolated pancreatic rat islets: Difference between glucose, tolbutamide and aminophylline. Endocrinology 91, 33-38 (1972)

4. Ammon, H.P.T.: Unpublished observations

5. Milner, R.D.G.: Stimulation of insulin secretion in vitro by essential amino acids. Lancet 1969 I, 1075-1076

6. Burr, I.M., Stauffacher, W., Balant, L., Renold, A.E., Grodsky, G.M.: Regulation of insulin release in perfused pancreatic tissue. Acta diabet. lat. 6, suppl. 1, $589-596$ (1969)

7. Basabe, J.C., Lopez, N.L., Viktora, J.K., Wolff, F.W.: Insulin secretion in the perfused rat pancreas. I. Effect of tolbutamide, leucine and arginine; their interaction with diazoxide, and relation to glucose. Diabetes 20, 449-456 (1971)

8. Levin, S.R., Grodsky, G.M., Hagura, R., Smith, D.F., Forsham, P.H.: Relationships between arginine and glucose in the induction of insulin secretion from the isolated, perfused rat pancreas. Endocrinology 90, $624-631(1972)$

9. Panten, U., Christians, J.: Effects of 2-endo-aminoroborane-2-carboxylic acid upon insulin secretion and fluorescence of reduced pyridine nucleotides of isolated perfused pancreatic islets. Arch. Pharm. 276, 55-62 (1973)

10. Malaisse, W.J., Malaisse-Lagae, F.: Stimulation of insulin secretion by noncarbohydrate metabolites. J. Lab. Clin. Med. 72, 438-448 (1968)

11. Efendic, S., Cerasi, E., Luft, R.: Role of glucose in arginine-induced insulin release in man. Metabolism 20, 568-579 (1971)

12. Kaneto, A., Kosaka, K.: Stimulation of glucagon secretion by arginine and histidine infused intrapancreatically. Endocrinology 88, 1239-1245 (1971)

13. French, J.W., Baum, D., Porte, D.: Multiphasic insulin response to arginine. Proc. Soc. Exp. Biol. Med. 137, 858-860 (1971)

14. Fajans, S.S., Floyd, J.S., jr., Knopf, R.F., Guntsche, E.M., Rull, J.A., Thiffault, Ch.A., Conn, J.W.: A difference in mechanism by which leucine and other amino acids induce insulin release. J. clin. Endocr. 27, $1600-1606$ (1967)

15. Goldsmith, S.J., Yalow, R.S., Berson, S.A.: Effects of 2-deoxy-glucose on insulin-secretory responses to intravenous glucose, glucagon, tolbutamide and arginine in man. Diabetes 19, 453-457 (1970)

16. Lucke, Ch., Kagan, A., Adelman, N., Glick, S.M.: Effect of 2-deoxy-D-glucose and mannoheptulose on the insulin response to amino acids in rabbits. Diabetes 21, $1-5(1972)$

17. Fajans, S.S., Quibrera, R., Pek, S., Floyd, J.C., jr., Christensen, H.N., Conn, J.W.: Stimulation of insulin release in the dog by a nonmetabolizable amino acid. Comparison with leucine and arginine. J. clin. Endocr. 33, 35-41 (1971)

18. Milner, R.D.G.: The mechanism by which leucine and arginine stimulate insulin release in vitro. Biochim. Biophys. Acta 192, 154-156 (1969)

19. Hellman, B., Sehlin, J., Täljedal, I.-B.: Effects of glucose and other modifiers of insulin release on the oxidative metabolism of amino acids in micro-dissected pancreatic islets. Biochem. J. 123, 513-521 (1971)

20. Snyder, P.J., Kashket, S., O'Sullivan, J.B.: Pentose cycle in isolated islets during glucose-stimulated insulin release. Amer. J. Physiol. 219, 876-880 (1970)

21. Ashcroft, S.J.H., Weerasinghe, L. C.C., Bassett, J.M., Randle, P.J.: The pentose cycle and insulin release in 
mouse pancreatic islets. Biochem. J. 126, 525-532 (1972)

22. Lacy, P.E., Kostianovsky, M.: Mothod for isolation of intact islets of Langerhans from the rat pancreas. Diabetes 16, 35-39 (1967)

23. Soeldner, J.S., Slone, D.: Critical variables in the radioimmunoassay of serum insulin using the double antibody technique. Diabetes 14, $771-779(1965)$

24. Herken, H., Lange, K., Kolbe, H. : Brain disorders by pharmacological blockade of the pentose-phosphate pathway. Biochem. biophys. Res. Comm. 36, 93-100 (1969)

25. Kolbe, H., Keller, K., Lange, K., Herken, H. : Studies of carbohydrate metabolism in rat kidney after pharmacologic blockade of the pentose phosphate pathway. Arch. Pharm. 271, 93-102 (1971)

26. Ammon, H.P.T., Patel, T. N., Steinke, J.: The role of the pentose phosphate shunt in glucose-induced insulin release: In vitro studies with 6 -aminonicotinamide, methylene blue, NAD, NADH, NADP, NADPH and nicotinamide on isolated pancreatic islets. Biochim. Biophys. Acta 297, 352-367 (1973)

27. Kaplan, N.O., Ciotti, M.M.: The 3-acetylpyridine analog of DPN. J. Amer. chem. Soc. 76, 1713-1714 (1954)
28. Kaplan, N. O., Ciotti, M.M., Stolzenbach, F. E. : Reaction of pyridine nucleotide analogues with dehydrogenases. J. biol. Chem. 221, 833-844 (1956)

29. Coper, H., Neubert, D.: Einfluß von NADP-analogen auf die Reaktionsgeschwindigkeit einiger NADP. bedürftiger Oxydoreduktasen. Biochim. Biophys. Acta 89, 23-32 (1964)

30. Ashcroft, S.J.F., Hedeskov, C.J., Randle, P.J.: Glucose metabolism in mouse pancreatic islets. Biochem. J. 118, 143-154 (1970)

31. Efendic, S., Cerasi, E., Luft, R.: Arginine-induced insulin release in relation to the cyclic AMP system in man. J. clin. Endocr. 34, 67-72 (1972)

32. Hellman, B., Idahl, L., Lernmark, A., Sehlin, J., Täljedal, I.: Role of thiol groups in insulin release: Studies with poorly permeating disulphides. Mol. Pharmacol. 9, 792-801 (1973)

M.J. MacDonald, M.D. Elliott P. Joslin Research Laboratory, Harvard Medical School, 170 Pilgrim Road Boston, Mass. 02215 USA 